
Research at the Home Office Police Research and
Planning Branch

Is a written answer in tho House of Commons on July 24, the Secretary of State, Home Dopartment, Mr. H. Brooke, stated that the principal subjects of research at present being undertaken by the Home Office Police Research and Planning Branch included: research into methods of dealing with serious and unsolved crimes, including an investigation into the possible extension throughout Britain of regional crime squads and criminal intelligence bureaux, and a study of criminal investigation techniques and improved scientific aids; an enquiry into the possible application of computers to fingerprints and other police records; an investigation of the policing of motorways and other through routes, including experiments with the use of a helicopter; investigation of the problem of devising a formula for accurately assessing police establishments.

\section{Scientific and Technological Man-power in Britain}

IN reply to a question in the House of Lords on July 15 , the Earl of Bessborough said that the output of qualified scientists had risen from 6,500 in 1959 to 9,600 in 1964 , and that of engineers from 8,800 to 9,900 a year, giving a total of scientific and technological man-power nearly one-third higher than in 1959. This total of $19,500 \mathrm{com}$ pared with the 20,000 set as the target for 1970 by the Man-power Committee in its 1956 report.

\section{Employment of Graduates}

The report of the University of Glasgow Appointments Committee for the year ended December 31, 1963, records that while competition for appointments was more severe, genorally this was met succossfully (Pp. 26. Glasgow: The University, 1964). The demand for mathematicians, physicists and electronic engineers continued to bo far in excess of supply, but chemists met a more difficult situation, and opportunities for geologists were hard to find outside South Africa. About 53 per cent of honours graduates in science took some form of postgraduate study; only 2 went overseas at that stage. Almost onethird of those with an ordinary degree in science entered the computer field. The number of men with honours degrees in arts or law entering industrial careers increased, but fewer with ordinary degrees did so. Only 39 honours graduates in arts and 50 men with ordinary degrees took up teaching, compared with 41 and 61 , respectively, in 1962; for science the corresponding figures for 1963 are 28 and 36, and for 1962, 23 and 37. In November 1963 it was decided to separate the two functions of Appoint. ments Secretary and Adviser of Studies in Science. For women students little change is noted in the general pattern of employment, although the number of openings in Scotland notified to science graduates rose from 34 to 59. Of the 307 graduating in arts, law, pure and applied science, 74 entered direct employment, 177 taking a teacher training course, an increase of 35 , but there was a considerable drop in the proportion of honours graduates in science entering teaching, and none of those graduating with honours in mathematics (or mathematics and another subject) did so.

\section{Regional Centres for Radiological Protection Services}

Tне Ministry of Health and the Medical Research Council have jointly set up four Regional Centres of the Radiological Protection Service at Birmingham, Leeds, Manchester and Glasgow. These Centres can now be used in connexion with radiation surveys of radiological establishments and advisory services (including advice on plans of radiological establishments). It is envisaged that, later in the year, the Centres will provide other services, such as personnel film monitoring, calibration of radiation-protection meters and leakage tests of sealod radioactive sources. The Radiological Protection Service, Clifton
Avenue, Belmont, Sutton, Surrey, will continue to provide services for establishments in south-east England. All establishments which at present make use of the film-monitoring and other services provided at Sutton will shortly be informed which Centros will provide future services for them.

\section{World Health Organization Reports}

THE valuable information published from time to time in the Technical Report Series of the World Health Organization is so well known and widely appreciated that it is scarcely necessary to direct the attention of our readers to it. Expert committees of the Organization have recently issued seven Reports, all of which are of great interest. No. 271 (Pp. 18. I Sw. fr.; 1s. 9d.) deals with Atmospheric Pollutants. Report No. 272 (Pp. 52. 2 Sw. fr.; 3s. 6d.) is the tenth report of the Export Committee on Malaria, and the continued success of the Organization's world-wide campaign against this disease is further discussed in detail in the W.H.O. Chronicle (18, No. 6; June 1964) under the title "Malaria Eradication in 1963", together with a map which shows at a glance the astonishing progress that has been mado and the hopeful outlook for the future. In 1963 the seventh International Congress on Tropical Medicine and Malaria was held at Rio de Janeiro, and a note on this Congress appears in the Boletin Chileno de Parasitologia (19, No. 1; 1964). This Congress was attended by 1,236 experts from 65 countries. Technical Roport No. 274 (Pp. $90.3 \mathrm{Sw}$. fr.; 5s.) deals with Biological Standardization; No. 275 (Pp. 27. 1 Sw. fr.; 1s. 9d.) reports on Psychosomatic Disorders; No. 276 (Pp. 53. 1 Sw. fr.; 3s. 6d.) is on The Prevention of Cancer; No. 278 (Pp. 48. 2 Sw. fr.; 3s. 6d.) is entitlod Postgraduate Preparation of Health Workers for Health Education. No. 277 (Pp. 69. $3 \mathrm{Sw} . \mathrm{fr} . ; 5 s$.$) is a valuable$ report by the Expert Committee on Helminthiases on Soil-transmitted Helminths, which are responsible for much illness, disability and economic loss among millions of human beings and domesticated animals. This Report discusses the extent and geographical distribution of these helminthic diseases, the factors which influence their transmission, their pathogenesis and clinical manifestations, the interrelations between the physiology and biochemistry of the parasites and their hosts, immunity to them, the techniques used to investigate them and methods of controlling thom, together with recommendations for research. Copies of the Reports are available from the World Health Organization, Geneva, or H.M. Stationery Office, London.

\section{The International Council of Scientific Unions}

The May 1964 issue of the ICSU Bulletin includes a preliminary report of the tenth general assembly of the International Council of Scientific Unions, Vienna, November 22-29, 1963, with exerpts from the presidential address (No. 1. Pp. 64. Rome: International Council of Scientific Unions, 1964). There are also brief reports on meetings of the International Unions (Pure and Applied Physics, Geological Sciences, Biological Sciences) as well as notes from various scientific unions, their committees, commissions and permanent services on present activities. A calendar of meetings during 1964 is included. The Yearbook of the International Council of Scientific Unions, 1964, besides the Calendar of Meetings for 1964, the lists of mernbers of the Executive Committee, Council, and of the various Committees, and Commissions and Executive Bodies of the Permanent Services, includes the statutes and rules of procedure of the Council, and the rules for scientific and special committees and their charters (Rome: International Council of Scientific Unions, 1964). Relations of the International Council with the United Nations Educational, Scientific and Cultural Organization, the World Meteorological Organization, etc., are outlined and, besides a list of addresses of international organizations, there is an 